\title{
Can we discover something new by looking at practices? Practice theory and the history of education
}

\author{
Podemos descubrir algo nuevo mirando a las \\ prácticas? Teoría de la práctica y \\ la historia de la educación
}

\section{Pouvons-nous découvrir quelque chose de neuf en examinant les pratiques? La théorie de la pratique et I'Histoire de l'éducation}

\author{
Sabine Reh \\ Humboldt University, Germany
}

\begin{abstract}
In dealing with the material side of educational institutions, and cultures of education and learning, research on the history of education offers new perspectives and research questions. Familiar sources are thus read anew or re-interpreted; new sources are tapped and even familiar categories and forms of thought are subjected to historical interrogation. A practice-theoretical perspective is concerned with linking the reconstruction and analysis of the devel-opment and evolution of 'pedagogical practices' and technologies. This includes their material conditions, as well as transformations of knowledge about growing up in a society, transfor-mations of 'pedagogical' types of thought and patterns of reflection, and the emergence of relevant institutions and organizations. In this context, no aspect is regarded as a linear conse-quence of another, neither are they treated as independent from each other. Yet the question remains open: What exactly does practice-theoretically oriented or practice-based research on the history of education actually do? And how can a perspective on practices reveal some-thing new in the history of education?
\end{abstract}

Key words: practice theory, history of education, practice-based research, pedagogical practices. 


\section{RESUMEN}

En relación con el lado material de las instituciones educativas y las culturas de la educación y del aprendizaje, las investigación en historia de la educación ofrece nuevas perspectivas y preguntas de investigación. Las fuentes familiares están siendo releídas o reinterpretadas; nuevas fuentes están siendo aprovechadas e incluso categorías familiares y formas de pensamiento están siendo sometidas al cuestionamiento histórico. La perspectiva teórico-práctica se preocupa de relacionar la reconstrucción y el análisis del desarrollo y evolución de las 'práctica pedagógicas' y las tecnologías. Esta incluye sus condiciones materiales, así como transforma-ciones del conocimiento sobre el crecimiento en un sociedad, transformaciones de tipos de pensamiento 'pedagógico' y patrones de reflexión, y la emergencia de instituciones y organi-zaciones relevantes. En este contexto, ningún aspecto es considerado como una consecuencia linear con referencia a otro, tampoco estos son tratados como independientes los unos del os otros. Todavía la pregunta permanece abierta: Qué es lo que hace en la historia de la educación la investigación de orientación teoríco-práctica o la fundamentada en la práctica? Y cómo puede un perspectiva sobre la práctica revelar algo nuevo en historia de la educación?

Descriptores: teoría de la práctica, historia de la educación, investigación basada en la práctica, prácticas pedagógicas.

\section{RÉSUMÉ}

En traitant du côté matériel des institutions d'éducation, et des cultures de l'éducation et de l'apprentissage, la recherche sur l'histoire de l'éducation offre de nouvelles perspectives et questions de recherche. Les sources familières sont ainsi relues ou réinterprétées; de nouvelles sources sont exploitées, et même des catégories et des formes de pensées familières sont sou-mises à l'interrogation historique. Une perspective pratico-théorique s'intéresse à faire le lien entre la reconstruction et l'analyse du développement et de l'évolution des "pratiques péda-gogiques» et les technologies. Ceci comprend leurs conditions matérielles ainsi que les trans-formations du savoir au sujet du fait de grandir dans une société, des trans-formations de type de pensées "pédagogiques» et des patrons de réflexions, ainsi que l'émergence d'institutions et d'organisations pertinentes. Dans ce contexte, aucun aspect n'est considéré comme une conséquence linéaire d'un autre, et traité comme indépendant l'un de l'autre. Néanmoins, la question reste ouverte: En réalité, que fait exactement la recherche sur l'histoire de l'éducation, orientée en théorie vers la pratique ou basée sur la pratique? Et comment une perspective sur les pratiques peut-elle révéler quelque chose de nouveau dans l'histoire de l'éducation?

Mots clés: théorie practice, histoire de l'éducation, la recherche axée sur la pratique, pratiques pédagogiques.

Two photographs taken by students and printed in school news-papers, the first from 1960 and the other from 1961, offer an unusual view on classrooms and the relationships of authority - as could easily be determined by means of both synchronic and diachronic comparison:

The chairs in the classroom have been put up, some have re-mained down. No students, no teacher to be seen. The writing on the board from the last math lesson has not been removed. A chalkboard eraser is on the floor. Nobody picked it up. The end of lessons? Holiday time? A drawer under the table looks like a trash can. Leftovers from mid-morning break, a rotting banana peel, can be seen. And a hairbrush has been stashed under the table - to style one's hair. Before the lesson, for the break? 


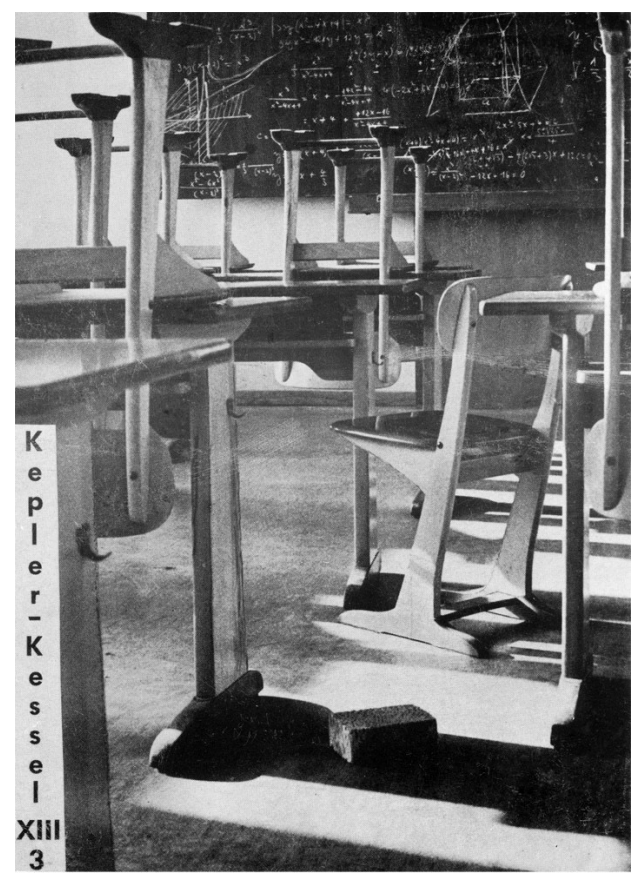

Practices and routines of schools and peer culture at the beginning of the 1960s in the Federal Republic of Germany are shown in these photographs in the very moment they were challenged. With the printing of these photographs in the school newspapers, spaces for play are reclaimed; that is what we do in school, ig-noring or circumventing some of the routines and rules, not putting everything away, not picking up a sponge that fell down, not cleaning the board, not finishing food and letting it rot, brushing one's hair.

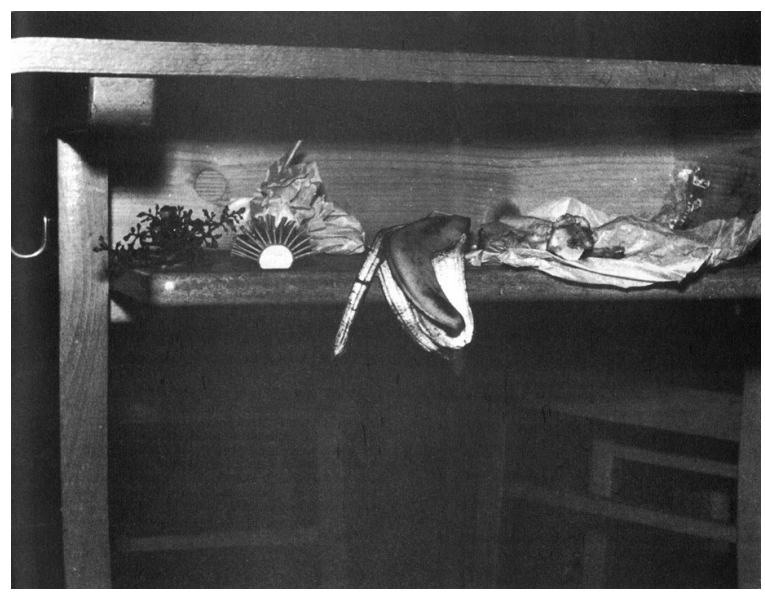


I N GERMANY, 'HISTORICAL WORK' HAS a tradition in education studies - and so has the complaint that it is not (or at least not properly) happening, or that it is not situated in the discipline. Meanwhile, there is no doubt that research on the history of education has been well established and can draw on a large body of research findings (Tenorth, 2009). Like historical and historiographical scholarship, research on the history of education is subject to many thematic and methodological trends. It does not simply react upon given developments in educational research and disciplinary-political conditions, such as changes in university curricula or new orientations in the promotion and funding of research. ${ }^{1}$ Of course, it also reacts upon epistemological turns - albeit sometimes with delay - regarding such rapidly evolving "re-orientations of theoretical-conceptual attention" (Bachmann-Medick, 2013, pp. 399-400) in the humanities and cultural studies (Casale, Oelkers, \& Tröhler, 2006). ${ }^{2}$ With a dispassionate reading, it is possible to detect a trend, regardless of all the putatively new approaches. There is a movement past strict dichotomies: language on one hand versus non-verbal reality on the other, mind versus body, subject versus object, human beings versus things, technology versus nature. 'Epistemologizing' and a simultaneous historicizing characterize new reflective approaches; hardly any term or phenomenon has escaped questions about its history, and hardly any observation has escaped questions about its problematic epistemological foundations.

In the past three decades, many social-historically oriented research on the history of education in Germany have primarily been concerned with investigating the history of structuredness and the conditions of growing up for young people, their acquisition of knowledge, and older generations' attempts to influence them (Groppe, 2012; Tenorth, 2009). ${ }^{4}$ Scholars analyzed political and institutional frameworks and, to some extent, the economic and technical-material conditions and practices of development.

For a number of years, the social-historical approach has been complemented by a new cultural-historical perspective - that is, by attention to material culture and its influences. This presents a new field of research concerning matters, practices, and routines by and in which artifacts are produced, while also questioning how these are effective in themselves. A "practice-theoretical perspective" has developed and, according to Tschopp's (2009) description of the cultural-studies-oriented focus in German historical research, the topic of concern is a reconstruction of "culturally coded practices of actors in history and material and intellectual products emerging from such practices" (p. 588). Such a perspective was debated even earlier at the international level. In the US, for instance, this is documented in contributions by Biernacki (1999, 2005). Here, he looks at consequences for research that emerge from an understanding of culture that is limited to a system of signs, arguing in favor of an expanded definition of culture.

In dealing with the material side of educational institutions, and cultures of education and learning, research on the history of education offers new perspectives and research questions. Familiar sources are thus read anew or re-interpreted; new sources are tapped and even familiar categories and forms of thought are subjected to historical interrogation. ${ }^{6}$ A practice-theoretical perspective is concerned with 
linking the reconstruction and analysis of the development and evolution of 'pedagogical practices' and technologies. This includes their material conditions, as well as transformations of knowledge about growing up in a society, transformations of 'pedagogical' types of thought and patterns of reflection, and the emergence of relevant institutions and organizations. In this context, no aspect is regarded as a linear consequence of another, nor are they treated as independent from each other. Yet the question remains open: What exactly does practice-theoretically oriented or practicebased research on the history of education actually do? And how can a perspective on practices reveal something new in the history of education? Possible answers to these questions are outlined below.

First, the precise theoretical assumptions of practice-theoretical research are briefly sketched, together with an outline of the situation of practice-theoretical approaches to historical studies in Germany. Next, approaches in German research on the history of education that draw on the term of 'practices' and possibly an underlying concept of a practice-theoretical historical research will be described. Two research projects from the Research Library on the History of Education (BBF) in Berlin are used to demonstrate where such an approach might provoke discomfort and new insights, and, finally, there is discussion of the problems and difficulties of the described perspective.

\section{Practice theory and historical science}

Füssel (2014b) recently gave a talk ${ }^{7}$ highlighting potentials and limitations of a practice theoretical historiography, which was at once theoretically informed and also critical of the results. The author (himself an early modern historian) identified the central problem of transferring such a research approach from social sciences and cultural studies. In those disciplines, practices are mostly researched from an ethnographic perspective - that is, in terms of participant observation. Outside of contemporary history and oral history methodology, witness reports on practices and daily routines of education are lacking, and moreover, past practices can no longer be observed. It is difficult to report on practices that represented routines that, in turn, were produced by and contained implicit knowledge. Based on remains of the past, practices can only be retrospectively reconstructed. Füssel thus cautions that "while the practicetheoretical approach has immensely enriched historical research and inspired a variety of innovative studies, there is a danger of on the one hand flattening-out and on the other over-theoretizing, as evident from the conference on Early Modern Age held in Munich in September 2013 on the topic of 'Practices in Early Modern Age"' (Füssel, 2014b, p. 2). ${ }^{8}$ What exactly does practice-theoretical history of education do, given that nowadays - within social history and meanwhile also within conceptual history (Begriffsgeschichte) - quantifying methods, lexicographical studies, and sometimes historical discourse analysis are used, and modern forms of intellectual history draw on different types of hermeneutics and rhetorical analyses (Füssel 2014b, p. 5)? Such is the justified question posed by Füssel.

To find an answer, it is necessary to first take the concept of practices seriously and strengthen it, as done by "practice theorists" such as Bourdieu (1979), ${ }^{9}$ Giddens 
(1995), or Schatzki (1996, 2001, 2010). Generally, cultures are assumed to be produced and reproduced in practices as related constructions of meaning and self-interpretations that are symbolically mediated several times and at different levels. Practices can be repeated; they are quasi-meaningful institutionalized forms of meaningful doings. They can be regarded as first forms of an institutionalization and the smallest social unit (Reckwitz, 2003). As variously described by Schatzki (2002), practices are "a set of bodily doings and sayings" (p. 73), "a bundle of activities" (p. 71), "organized by tasks and projects" - an "open, temporally unfolding nexus of actions," "that people directly perform" (p. 72). That is to say, people "perform them not by way of doing something else." The doings and sayings composing practices are linked through practical understanding, rules, a teleoaffective structure, and general understandings (Schatzki, 2002, pp. 59-122).

Accordingly, the human body is also taken into a historical perspective as a bearer of routine knowledge - that is, tacit knowledge or tacit knowing (Polanyi, 1985), or a habitus that can interpreted as a structured and at the same time structuring construct (Bourdieu, 1979, p. 188). The body's doing and knowing should not only be understood as a mental structuring, but also as a physical routine in daily practice (Sarasin, 2013). Practices and routines have stored a somewhat practical knowledge: by their participation in them, individuals are socialized as subjects (Alkemeyer, 2013; Ricken, 2013 $)^{10}$; material and mental dimensions of cultures are thus socially conveyed. We can comprehend material dimensions in terms of what can serve as sign or symbol; mental dimensions refer to the immaterial (geistig) nature of knowledge, moods, emotions, and systems of values.

Such a practice-theoretical understanding of cultures, and the individuals subjectified by productive practices and participation therein, can thus be delimited from a "culture as text" as proposed by Geertz (1983) in his "thick descriptions" - a cultural studies "mentalism," as Reckwitz (2000, p. 588) criticized it. Even if it remains unclear precisely how the relationship between mind (that is, mental, emotional, and affective systems of knowledge), physical behavioral routines, and artifacts is to be defined (Reckwitz, 2000, p. 590), such an understanding can assist in avoiding a Cartesian dualism of body versus mind and the contraposition of subject and object.

With respect to the initial question - namely, what distinguishes a practice-theoretical approach to historical research and what benefit might be gained? - Füssel offers an interesting conclusion. On one hand, processes of working with historical material (such as searching for, organizing/indexing, and reconstructing sources) do not seem to differ from "the hermeneutical standard procedure of historical research"12 (Füssel 2014 b, p. 9), though the research questions and hypotheses and the interpretation of findings are oriented differently, as Füssel (2006) demonstrates through his own research on practices of corporate rank order in the Early Modern era. On the other hand, further elements of the approach do, in fact, reveal a difference. To demonstrate this by Füssel's example, income, taxation, and the like are not important in order to reconstruct rank differences in corporate society, but do aid in tracing the reproduction of rank-based inequality in daily practices. It is here that the persistence of routines of distinction is displayed, the "performative practice" whereby individual 
claims for status or a general "guiding principle of inequality" (Füssel, 2014b, p. 9) is reinforced. At the same time, deviations in repetition of practices as "temporary subversions" need not be stylized as "self-determination" of autonomous historical subjects. But, for example, legal disputes relating to the disregard of distinction routines that can be found in the material confirm the existence of such rank orders as they indicate negotiation practices. The practice-theoretician does not seek to produce a histoire total and thus no attempt is made to conduct case studies; the point is not to determine who won a legal dispute, but rather to demonstrate that practices can be repeatedly identified in similar ways (otherwise they would not be practices). A practice theoretician does not reconstruct individual incidents, but might instead even question their status as such; Füssel does so for the incident of "battles" (Füssel \& Sikora, 2014). This means that a practice-theoretically oriented historian is interested in repetitions and small deviations, in 'series' and a panorama of practices, and needs to adapt research strategies accordingly. Moreover, the practice-theoretical approach does not contextualize singular occurrences, but tries to pinpoint practices according to a particular time and location. Füssel (2014b ) thus concludes that a practicetheoretically focused approach, one that is based on contemporary observable practices and investigates their genealogy, is particularly suited to avoid "conventional enemies of historicization" - that is, "much-taught anthropological consistency" and "anachronism" (p. 11).

Can we detect similar new trends in research on the history of education as those described by Füssel for early modern History? This question will be addressed below.

\section{Practices in educational historical research: Explorations, irrita- tions, and new questions}

In recent years, numerous studies have been published on processes of institutionalization of the transfer of knowledge. Many of these operate with the concept, or at least the term, of 'practices.' Taken together, they demonstrate a potential for a practice-theoretical approach to an alternative history of school as an institution and school-based instruction. It is evident that practices directed toward knowledge acquisition/learning or knowledge transfer/teaching existed in entirely different contexts than were present in the institutional precursors of schools. Even prior to the establishment of compulsory education, large parts of the population were already able to read and possibly write. ${ }^{13}$ The same is true of arithmetic and accounting, as recently described by Schläppi (2013). The author uses the term "learning practices" (Lernpraktik), explicitly drawing upon though without referring to Giddens; he emphasizes that one can easily discern educational strategies geared toward practical knowledge for early modern elites (who were far from being averse to education). According to Schläppi, "the cultural technologies of arithmetic and accountancy can demonstrate the divide between enlightenment educational ideals and daily learning practices" (p. 235). Education was not understood as a means of social advancement, but rather as the improvement of one's own sphere of activity; this latter end drove the acquisition and training of situational know-how. Practical skills, including those required for administrative positions, were normally not acquired in formalized 
educational programs, but rather 'on the job.' With this in mind, it is possible to once more ask how, where, and in what way it was possible to learn easily or efficiently, and additionally where school and instructional practices drew on practices that developed elsewhere. In this context, it is possible to describe other continuities and discontinuities of knowledge transfer and knowledge acquisition practices.

However, it is not only interesting to look at practices of teaching (that is, knowledge transfer) outside modern assumptions about institutionalization; this also raises the question of self-concept and legitimization, or the authority of those who could or should transfer knowledge. Here one might consider Sita Steckel's 2011 doctoral thesis in medieval history, which looks at practices of knowledge transfer in the Early and Late Middle Age and focuses on how individuals were legitimized or "authorized" as transferors of knowledge.

Steckel employs a practice-theoretical approach to demonstrate how lecturers were legitimized between the Early Middle Ages (8th-9th century) and Late Middle Ages (11th-12th century), and thus authorized to transfer knowledge. In her criticism of some earlier work on the history of schools in the Middle Age, Steckel argues that scholars' modern conceptualizations of institutions elide important and central processes of knowledge transfer and knowledge acquisition. This can result in an exclusive focus on knowledge transfer in terms that align with a modern - and anachronistic - understanding. Informal forms of knowledge transfer or concepts of teaching in the form of doctrina and disciplina are largely left aside. Instead, Steckel identifies a continual process of learning and socialization, comparable to a lifestyle mediated by intellectual knowledge (as, for example, in monasteries).

Knowledge transfer concerns continuously practiced training of a monk's life - not simply instructional transfer, but tied to the charisma of a community (cf. Steckel, 2011, p. 94). As Steckel's intention is to assess the role of teachers (that is, those who transfer knowledge), she cannot assume school to be the fundamental institution, but rather spiritual communities (p. 96). Knowledge transfer did not primarily or exclusively (and, perhaps, not even primarily) happen in settings we would understand as schools today. It occurred in different practices: in different places and in encounters according to a variety of schedules, in discussions among beginners and advanced experts, by self-instruction, by reading, and so on. Steckel's interest in teachers, teaching, and authorization raises the issue of sources and documents. She argues that texts concerned with ideas about teaching even without explicit reference to the practice of teaching still allow for deducing rights and duties assigned to specific groups, and it is also possible to tap into biographical sources that "inform about the communicative practice of knowledge transfer" (p. 98). For instance, Steckel argues, letters she has analyzed reveal a communicative as well as an informative function - in other words, they do not only concern the level of an object of communication, but a level of action at which a sender positions him- or herself in relation to the recipient(s) (p. 154). Moreover, Steckel reconstructs text dedications as communicative practices, whereas they have previously only been analyzed in terms of adoption and concern with classical topics and metaphors. Thus, she conceives the establishment of an author's identity as a social act and describes how individual 
authors legitimize their function as public narrator or writer.

Steckel (2011) roughly distinguishes two different strategies. One of these though rare in the Early Middle Ages - is an "existential authorization," whereby an individual seems legitimate by virtue of a vocation or divine vision, a spiritual conversion. The legitimation is rooted in and perhaps constituted by the individuality of an "enlightened person" and uncommutable personal characteristics and possibly skills (p. 1195). The other type of legitimization is more common to this period: a religious authority whereby authors simultaneously position themselves vis-à-vis "divine truth" and a third party who requested them to write. A life of virtue qualifies the individual to have insight into true knowledge provided by divine influence. It was not their own willpower or the belief in their own skills that enabled individuals to write, but their being requested to do so in accordance with and by virtue of their genealogical relationship to an authenticating - that is, churchly - tradition. This request was corroborated by ritualized procedures, for instance hesitation in acceptance, request for examination, and improvement of one's own writings. Religious authorization might be detached from an individual bearer because in the course of time, rules for dealing with knowledge were more precisely defined, and these in turn were easy to administer and apply, particularly because writing as the production and dissemination of knowledge became a 'craft.' These historical reconstructions and the evidence for two different patterns of communicative practices in legitimizing knowledge transfer offer a link for a history of professional authorization practices. For example, they can be compared to the autobiographical educational narratives of the early 19th century - as with the life stories of teachers collected by Diesterweg (1835). The teachers, whom Diesterweg asked to write out their experiences, repeatedly called upon tropes of pedagogical love, thereby possibly offering a contrast to a certain form of 'expert' knowledge that is viewed as scientific (Reh, 2014).

Below, two examples will be given to indicate how, in research on the history of education, a practice-theoretical perspective might cause provocation, particularly with respect to not entirely insignificant narratives that foster identity in the German history of education.

\subsection{Observational practices: A new perspective on the evolution of education science between empirical research and professional action}

One of the central - and one might even say traumatic - topics of education science as a discipline in Germany concerns the study of its "pre-history" or its beginning (Tenorth, 2004, p. 341). Despite contemporary announcements that were more optimistic and despite later attempts to date the beginning of education science to the 18 th century, there currently is no general agreement regarding the theoretical status of education science, its disciplinary nature, its science theoretical background, or its institutional localization (Tenorth, 2004, p. 342). On one hand, philanthropists were regarded as bearers of pre-disciplinary education and instruction in the last third of the 18th century. On the other hand, after 1820 school pedagogy was identified as a form of knowledge that successfully led to "scientification," albeit in a narrow sense 
(Brachmann, 2008). Some authors argue that philanthropists had taken a sciencebased approach, aiming to reach education principles by induction, subjecting them to the test of experience and reason. Experience-based knowledge was important, as it could be gained from observation and trial (Kersting, 1992, p. 89).

Even if the philanthropists cannot be regarded as the originators of the discipline, Brachmann (2008) argues, the development of modern science led to an overlaying of life-world knowledge by a rationalist, instrumental (masculine, professional) knowledge. Brachmann finds that at the end of the 18th century, no ambitions had emerged regarding the establishment of the discipline in its own right, despite the existence of a "communication community" that engaged in periodical publishing (p. 375). Brachmann states that disciplinary structures in education science were insufficiently established and concentrated, and refers to "dabblers in publishing" in education science. He implies that it was already clear what was meant by "education science." Otherwise, it would not be possible to dabble, as no standards would exist in the field - to which Brachmann refers in a slightly un-historic manner. After 1800, public school practitioners entered the publishing stage and "occupied relevant discourse" (p. 376), and as "eclectics" and "peripheral professionals," collected the dispersed knowledge and categorized and systematized it. After 1820, the scientifically inspired milieu of professional practitioners from public schools (Volksschulen) became established. This milieu was longer focused on the knowledge immediately necessary for teaching practice. Pedagogical knowledge was hardly conceived in terms of educational-scientific, systematic insights, but rather generalizable school pedagogy and general didactic ideas (p. 378).

In these debates, it is difficult to distinguish clearly between "expertification" of knowledge, "scientification," and "professionalization" of the actors involved (Kersting, 1992, p. 71) - not least because such a differentiation only emerged at the time. The historiography of pedagogical knowledge in its various forms might (as is postulated in this article) benefit considerably from looking at practices of knowledge production. Regarding the time discussed here, observation constituted a central practice for the production of knowledge that was ultimately regarded as "scientific." Two crucial moments can be discerned in the "Empire of Observation," as science historian Lorraine Daston (2011) calls the two hundred years between 1600 and 1800. First, by documenting observations in tables in a particular style, a single element is brought into focus. This element can be dissected and synthesized. Second, an increasing documentation of time-points of observation indicates attention to change over time. Dates and occasionally exact times are recorded in the tables along with the observations.

Time-consuming observation - practically a way of life - is always an observation of a singular incident or element in the "Empire of Observation." The material thing or event may be seen as an exemplar of something else or something entirely singular. The new natural science regimes of observation thereby reveal something that will ultimately be defined as "pedagogical"; observation always focuses on a singular incident, a single thing, and observation that is located at a particular dimension in time permits the identification of change. It is then possible to code change in terms 
of development.

The observation of 'external' nature or the natural world became a nearly universal model of discovery and source of knowledge; in the course of the 18th century, the human being also emerged as an object of scientific observation (Moravia, 1973, p. 18). Anthropology became the "central science of the time" and could even be regarded as a "radical science of Enlightenment." Observation-based knowledge about human beings was to be gained and used for the benefit of mankind. It was deemed appropriate to make observations of "wild" and "not yet civilized" people encountered while traveling. (p. 123), and thus make observations on "the development of the first skills practiced by mankind" (pp. 212-214). ${ }^{14}$ Children also became an object of observation, as they did not yet seem to be spoilt by artificial civilization. To a similar end, scientists observed individuals with disabilities or who displayed delayed or problematic development, for instance for studies about language acquisition of the deaf (p. 217). Appeals were made not only to school teachers but to home tutors, doctors, or priests to share their observations, as well (Diele \& Schmid, 2010).

However, the calls brought forward by researchers and enlighteners (particularly philanthropists) requesting documentation and publication of observations on children did not provoke overwhelming responses. Neither Karl Philipp Moritz in his Magazin zur Erfahrungsseelenkunde ${ }^{15}$ nor Schlözer's 1771 request to educators to write observational diaries, nor Campe's call to report anecdotal incidents in "father diaries" or "education stories" (followed up by Wezel) were marked by great success (Diele \& Schmid, 2010). While Diele and Schmid described this era as the beginning of empirical research on children, contemporaries regarded such observations simply as "pedagogical observations." Unlike in the natural sciences, whose practitioners of observational methods had already established themselves as researchers and therefore published under their full names, quite a number of pedagogical articles based on observational methods were published without attribution or the author's full name (Diele \& Schmid, 2010).

Pedagogical observations were sought in the context of pedagogical action, as documented by respective actors (that is, pedagogues) - but doubts are also raised regarding the feasibility and relevance of such practices. For instance, Wezel (1778) states that first of all a "cold observer" is necessary. However, the practitioners themselves experienced difficulties and documented little. Around the mid-19th century, the first handbook articles on pedagogical observation indicated some of these difficulties - and here, one should note that these difficulties were not only different than those identified by the similarly newly established natural sciences, but that they came about 100 years later (Daston, 2011). The manual indicates: "At stake is not supervision, but observation. Supervision explicitly involves the intervention in the supervised subject matter - that is, a practical behavior. The observer, by contrast, behaves completely receptively toward the subject matter; he leaves it [the subject] be in order to know it better and let it impress upon his mind. Observation is thus a purely theoretical procedure." 16

In their schools and educational facilities, philanthropists applied the concepts of observation and principles of a science of studying human beings, adopting practices 
from natural scientists and combining these with practices from educational institutions. ${ }^{17}$ By adopting tables and books of merit, they embraced the practices of documentation and competition (which had developed mainly in Jesuit and Pietist institutions), while also taking on the documentation and registration systems that had been developed in the observational practices of the natural sciences. This is evidenced by the merit books Campe began to keep in 1777 in Dessau, which demonstrate a close proximity to observations in natural science. One can see this proximity, for example, in the columns in which information on students was recorded. ${ }^{18}$ This demonstrates a blending and re-contextualization of practices.

For their educational practice at school, the philanthropists made recourse to a reporting system which was developed in natural sciences. This made it possible to capture and document the 'pedagogical' element - interest in individual children, their particularities and idiosyncrasies and changes over time. Here one might refer to 'pedagogization' of observational regimes. But interestingly, in their efforts to establish education as a scientific discipline, the enlighteners and philanthropists proposed a form of recording and publishing different than in the natural sciences, and which was similar to the later hermeneutical and historical sciences. Observations should be recorded in narrative form, sometimes as stories, indicating a need to document a specific kind of temporal meaning - individual development.

Observation developed in context of the pedagogical sphere and its institutionalization and came to involve the school-based observation of individuals, conducted in a way that put an ever-growing emphasis on change over time and on differences between individuals. Mid-19th century school observation seemed to assume that no observation would be necessary if everyone were the same (Baur, 1859). ${ }^{19}$ Observation played a central role in the development of professional teachers. Observation presupposes presence, and professional pedagogues are legitimized through witnessing. Observation interpellates not just the recipient of pedagogical attention, but also the pedagogue him- or herself, who is not merely observing, but also coming into being as a professional pedagogue.

But, in fact, the implementation of an observation regime and the thematization of pedagogical observation did not lead to the institutionalization of a pedagogical empirical science. Rather, they contributed to the establishment of a community of practice, by the institutionalization of professional teacher practices - teaching staff can now talk about their observation. A sort of 'control' or "checking-in' enables the staff to agree upon and ensure 'objective' evaluations based on sound observation. ${ }^{20}$ Such observations and subsequent assessments assigned to individuals in terms of 'achievement' thus produce the individuality of students. From the beginning of its institutionalization, pedagogical observation was thus tied to presumed or recognized individuality, and additionally to the introduction of a time dimension as an aspect of observation - both of these resulting in benchmarks and assessments.

By reconstructing the pre-history of education studies in the German-speaking realm - rather than trying to systematize or ascribe theoretical positioning to the practices through and with which knowledge about growing up was organized - we stumble upon a potentially irritating finding: the constitution of the profession and 
the professional community is based on practices that originated in the new natural sciences as practices of the methodized generation of knowledge. This corroborates Brachmann's (2008) point about publication practices, but on a different level (and, indeed, without having to argue ahistorically): the reception and adaptation of knowledge practices is different than previously thought, and these different and reclaimed forms of observational and experiential knowledge reveal the early stages of the pedagogical field.

\subsection{Reading practices in "German lessons" tory of school lessons}

An episode from the history of the establishment of school lessons may serve here as a second case, in which the potential of practice-theoretically oriented research on the history of education can be highlighted. Writing the history of German lessons was for a long time the research of the programmatic outlines of didactic action in German lessons, partly via the curriculum. ${ }^{22}$ In this history, a central narrative has become prevalent: at the latest in the mid-19th century, two fundamentally different ways of dealing with literature in lessons emerge. While some argued for an analytical approach to literature, a dissection (Zergliederung), others put capturing the aesthetic quality of literature as a form of holistic perception as the central goal. In the following, it will be demonstrated that this history may be explained very differently when one attempts to reconstruct which practices in German lessons determined the approach to literature - thus resolving an element of the entrenched controversy.

At the beginning of the 19th century, the teaching of German literature in the Gymnasien (secondary schools) of many German-speaking states took the form of directed readings done as homework. The Second Prussian Abiturreglement of July 25, 1812 (a law establishing the Abitur as the official qualification) required that students be familiar with the finest works of German authors in their historic context (Matthias, 1907). Difficulties in reading were hardly expected, in contrast to those associated with the readings of Greek classics, so why should class time be dedicated to it? But, indeed, in the course of the first half of the 19th century, reading German literature made its way into classroom lesson practices.

1842 was an important year in the establishment of theretofore precarious "German lessons" as a subject at Gymnasien. In this year in Leipzig, German Lessons at German Gymnasien: A Pedagogical Experiment was published for the first time. The book, written by Robert Heinrich Hiecke, teacher and schoolmaster of a Gymnasium, enjoyed many editions and is often seen as the first didactic work on literature. Not only does research into the history of German lessons and into Hiecke ${ }^{23}$ confirm that his methods prevailed, these methods are referenced even today (Paefgen, 2006). It also constructs or projects onto on him and the authors Philipp Wackernagel $(1851)^{24}$ and Rudolf von Raumer (1897), ${ }^{25}$ his alleged opponents, that seemingly timeless controversy surrounding the approach to German literature in lessons. That is, in these men (or their writings), the research identifies either an analytical approach to German literature (Hiecke) or a non-reflective appreciation and excitement for the beautiful. ${ }^{26}$

Hiecke argues for the recognition of the importance of lessons in and on the 
mother tongue. ${ }^{27}$ German literary works should also be taught, even though they might seem easy to understand due to being in their native language. Teaching true reading becomes the task of the school - to produce attentive readers who are not prone simply to glancing over the words, dismissed as Leserei, "reading mania." It is about being able to explain the text in the class reading, turning the lesson hours into interpretation hours and not leaving the reading to be completed by the individual at home.

Hiecke's (1842) argument about teaching literature is threefold: literature must be discussed and explained in order for it to be productively processed, and ultimately it is desirable to allow the possibility for artistic endeavors in recitation. The methodical steps in "the process of interpretation" (p. 122) were not only already used by teachers in schools, ${ }^{28}$ but were also familiar to parents, as Hiecke stated. Reading aloud is followed by the explanation, first of the summary of the contents and then of specific linguistic difficulties. One could then return to the contents and portray the "tenor" of the whole by working on an outline in which the main thought and the secondary objects are reconstructed. Exercises (or rather, steps in the process) follow, with whose help students may gain proximity to the text "with as free a position as is possible to that which has been read" (p. 132). In some cases, these exercises differ for prose and poetic texts. The latter necessitates, above all, the aesthetic understanding. It is about the reflection of the form of the whole and the portrayal in itself (p. 136). For the discussion of the poem "as a poem" (p. 147), Hiecke suggests a parallel method (p. 156). Even - or perhaps precisely - for simple poems there is much to say: "This poem can be understood (what we call understanding) by any first-grader; no word, no construction which is requiring of explanation, equally no functional difficulty; nothing from which the youngest of secondary schoolers should prove a challenge with the full assistance of the teacher. But does he really understand it for that reason? Naturally, not for the reason that the prevailing feeling is quite foreign to him. It would be madness to allow him to read this poem" (p. 147).

Two matters are at stake. Firstly, there is an aesthetic understanding of poetry, the significance of the sound, the favorable choice of expression, the economy of the poem (Hiecke, 1842, pp.160-161). Secondly, it is about finding that which is not in the poem directly, but recognizing and understanding the ideas, the "interior," which runs through the poem which "as the soul, runs through the body and makes it come alive, but is only visible in certain places, like the eyes of the poem poking out on the surface" (pp. 161-162).

Hiecke on one hand and Wackernagel and von Raumer on the other seem to reach different conclusions on what to do with the text or the poem in the classroom. Wackernagel (1851) suggests reading aloud (p. 21) and oral and written reproduction - but all of these at home (p. 96). Von Raumer (1897) finds it best that the teacher and then, after an appropriate amount of time, the students, read aloud, and then the students learn the text by heart (p. 225-230). "Silent, individual reading is a mere stopgap," he concludes (p. 227).

Undisputed, despite different didactic recommendations, is that in the first half of the 19 th century, class reading was cemented as a practice. There were different kinds 
of reading, but above all there was the reading aloud of German literary texts in class. The didactic texts and the methodological suggestions support this conclusion. For all three of the authors quoted, it is true that the practices that serve the explanation of the text and reading comprehension should at the same time achieve a distancing of sorts - a protection from cultural practices of entertainment as well as the discovery of an "interior" to be understood - of the poem as well as of the self, and to make it experienceable. The practice of reading aloud anchors the search for a hidden meaning, which, rather than being easy, always contains the possibility of failure. For this reason, the endeavor represents a real achievement for the student. Reading aloud was not just a test to see if the text has been understood correctly. It is also a warmup exercise for the demonstration of interpretation and understanding. Practices of in-class reading achieved the differentiation of the student as a hermeneutic reader ${ }^{29}$ from the poet, the author of the text.

An overview of class practices in German lessons does more than lead us to reject the strict dichotomization of different didactic approaches. It also brings the defining narrative of the history of lessons into question. Just this constituent phase of German lessons as a subject can be explained differently with the practice-theoretical perspective. Kittler (2003) saw the meaning of German lessons in the Gymnasium above all in the Abitur essay - society ultimately needed civil servants who could write - and to this end, private reading played a definite preparatory role: it encouraged the "production of imagination" (p. 185). Yet, otherwise, one could completely do away with reading in lessons. With attention to practices, this conclusion should be modified. Particularly when taking into account the class reading that prevailed and the uncontroversial practice of reading aloud, Kittler's position becomes untenable: schools do not disregard or write-off reading. Instead 'reading' itself - as understanding and interpretation, as guided imaginative production - needs to be practiced in schools.

\section{Conclusion: Challenges and boundaries of a historic praxeology in educational research}

This article drew upon a variety of studies: a dissertation on teaching and authorisation practices in Medieval times; smaller studies about the meaning of observation practices in the second half of the 18th century, which was a unique phase in the constitution of professional 'pedagogical' knowledge; and reviews on published literature on class practices in German lessons at the Gymnasium in the first half of the 19th century. Together, these show what can be gained from practice-theoretically oriented history of education. This approach seems to allow us to get 'closer' to the goings-on of the classroom. We gain proximity to the teacher's actions and interactions with students, and not only the explicit but also the implicit norms that may be approached by reproducing classroom orders and practices. Whereby here it could be shown how this occurred via a new line of questioning, of mostly published sources, large-scale investigations of other and older kinds of sources are necessary, as well. This would allow for new lines of analysis - perhaps even for longue durée or comparative projects.

Routines - and practices are routinized - are seldomly reported as routines. As 
they more or less become a malady for those participating when they no longer work, they trigger the search for new practices. It is beneficial to analyze the 'didactic journals' that gradually established themselves over the course of the 19th century for evidence of the new practices. Such an analysis of the journals requires reading not just the central article, but also the accompanying rubrics, the references, and then the announcements; this casts light on the complaints of teachers, particularly when these complaints are the result of different interventions, new material conditions in schools, new buildings, new furniture, and so on that required teachers to change their routines - and this, of course, indicates what their routines were, in the first place (Depaepe, 2000). Routines and practices can also be discerned from the analysis of individual test documents or students' documents from lessons (which must partly be newly collated) or from lesson plans of teaching staff, autobiographical texts, and other ego-documents. One can discover which activities are recurrent, though rarely mentioned.

Non-text artifacts reveal the use of certain media in lessons, noticeable from their traces: one might find insight into practices from illustrated sources, such as pictures or photographs. Artifacts reference the physical-material dimension of actions and practices. In this way, the photos printed with this article makes visible classroom practices and rules, and at the same time are to be interpreted itself as the practice of interschool communication, as a careful circumvention of rules and normative ideas. In this way, they convey a message about order - even of relationships of authority and also the possibility of research on transformation of classroom orders.

A 'getting closer' to lessons or the practices of the teaching personnel as is described here is not valuable or important in and of itself. That would ultimately advance the romantic ideas about the 'everyday life' and the 'little people.' Rather, the approach is of interest because it offers insights into longer-term transformation processes. Thus the history of "becoming a subject" and "losing subject status" (Verfachlichung und Entfachlichung) of instruction, teaching, imparting knowledge, or whatever the knowledge practices may be, are discursively processed. Their institutionalization is revealed to have new conjunctures and upheavals that may not match the commonlyaccepted terms of debate.

\section{Notes}

1. For example, see Groppe, C. (2012). History of education in Germany: Historic development - Results - raison d'etre. In J. E. Larsen (Ed.), Knowledge, politics and the history of education (pp. 179-193). Berlin, Germany: LIT. For a critical view, see Tröhler, D. (2011). Historiographische Herausforderungen der Bildungsgeschichte. Bildungsgeschichte: International Journal for the Historiography of Education, 1(1), 9-22.

2. The history of education is itself historical, and could be interrogated regarding its undiscussed and thus un-historicized presumptions and categories and cultural differences. Regarding categories, see Fendler, L. (2013). There are no 
independent variables in history. In T. S. Popkewitz (Ed.), Rethinking the history of education: Transnational perspectives on its questions, methods, and knowledge (pp. 223-244). New York, NY: Palgrave MacMillan. For this and for national developmental paths and different research priorities, see Heinemann, M. (Ed.). (1979, 1985). Die bistorische Pädagogik in Europa und den USA. Berichte über die historische Bildungs-forschung (Part 1, Part 2). Stuttgart, Germany: Klett-Cotta; Larsen, J. E. (Ed.). (2012). Knowledge, politics and the history of education. Berlin, Germany: LIT; Popkewitz, T. S. (2013). Styles of reason: Historicism, historicizing, and the history of education. In T. S Popkewitz (Ed.), Rethinking the history of education: Transnational perspectives on its questions, methods, and knowledge (pp. 1-26). New York, NY: Palgrave MacMillan. The latter perceives the situation and traditional orientation of American research on the history of education as special, and takes it as a starting point for a collection of international contributions to distinguish different styles of thought respectively historical work; one might refer to a "historist" and a "historicizing" style.

3. See, for example, Latour's criticism of "tidying up" in old European disciplines. Latour, B. (2008). Wir sind nie modern gewesen: Versuch einer symmetrischen Anthropologie. Frankfurt, Germany: Suhrkamp.

4. At different times, these processes are obviously conceived as something different - for example, as 'pedagogy' or 'education,' as 'socialization,' as 'teaching and learning' at school, as 'knowledge transfer' and 'competence acquisition' in the course of life. According to the position that is supported here, research in the history of education should not simply adopt contemporary concepts, neither should it 'extend' such present concepts 'into the past,' but instead treat and study them as historical.

5. The term "practice theory" (and adjective phrase practice-theoretical) has been chosen as the nearest and best translation for a term that has informed a major debate among German sociologists and historians (particularly of the early modern period): Praxeologie (and praxeologisch). Some German-language literature also refers to Praxistheorie, and both terms draw upon the work of theorists like Bourdieu, Giddens, and Schatzki. At any rate, the concept of 'practices' is at once of key importance and something other than a 'praxis' (which itself consists of practices). But the search for a proper translation of this specialist term reflects not only the linguistic nuances of translation, but also the fact that the historiographical and theoretical debates are somewhat differently framed and oriented in Germany and North America. While English-language historians and sociologists have certainly also critiqued newer cultural-theoretical approaches (see Spiegel, G. M. (Ed.). (2005). Practicing history: New directions in historical writing after the linguistic turn. New York, NY, and London, England: Routledge.), and particularly their heavy emphasis on symbols and language, I am not aware of an English literature that theorizes practices in this way and makes mention of the term "praxeology."

6. For an international perspective, see, for example, Lawn, M., \& Grosvenor, I. (Eds.). Materialities of schooling: Design, technology, objects, routines. Oxford, England: Symposium Books. For research on the history of education in German on spaces, see Jehlich, F., \& Kemnitz, H. (Eds.). (2003). Die pädagogische Gestaltung des Raums: Geschichte und Modernität. Bad Heilbrunn, Germany: Klinkhardt. For research on 
materialities, see Priem, K., König, G. M., \& Casale, R. (2012). Die Materialität der Erziehung: Kulturelle und soziale Aspekte pädagogischer Objekte: Einleitung zum Beiheft. In K. Priem, G. M. König, \& R. Casale (Eds.), Die Materialität der Erziehung: Kulturelle und soziale Aspekte pädagogischer Objekte (58. Beiheft der Zeitschrift für Pädagogik, pp. 7-13). Weinheim, Germany: Beltz.

7. A revised version of the talk will be published in a collective work that is currently in print. The author kindly provided a pre-print manuscript.

8. Such "over-theorizing" can be found in a text by historian Reinhardt (2007), one of the first to summarize practice theoretical approaches in German and international history. Regarding practical meaning of such an approach, he remains imprecise, stating that "the relationship between bodily behavior, routines, collective patterns of meaning and subjective assignments of meaning of historical actors as well as historical grounding of their identities and symbols becomes a central objective of analysis and theory building. Practice theoretical history strives to link micro and macro levels of history and links social historical analysis of social milieus, insti-tutions and social networks with culture-historical investigations of styles of thought, behavioral patterns and discourse” (p. 45). See also Raphael, O., \& Blaschke, L. (2007). Im Kampf um Positionen: Änderungen im Feld der französischen und deutschen Geschichtswissenschaft nach 1945. In J. Eckel \& T. Etzemüller (Eds.), Neue Zugänge zur Geschichte der Geschichtswissenschaft (pp. 69-109). Göttingen, Germany: Wallstein.

9. Practice-theoretical historiography strongly refers to Bourdieu; this might open up perspectives for linking the two assumptions that are so far discussed as controversial, because Bourdieu also plays a key role in German social history (for example, Hans-Ulrich Wehler) - that is, a culture-theoretically oriented historical science in terms of practice theory and a social scientific approach. For a similar estimation of Bourdieu's role regarding the discourse between social science and culture historical approaches, see Füssel (2014b).

10. Against this background, "mind" and "goals and intentions" can be regarded as stored in practices and they need not be perceived as mental dispositions exclusively at the level of an obsolete subject. Even if the subject is conceived as one that is not entirely aware of itself, thus it does not act autonomously and in its own right, it need not be treated as a simple illusion. Rather, as Reddy (2001) indicates, the individual can appear as a node - a "disaggregated self" (p. 95), faced by certain "translation tasks," it copes with in different ways depending on the state of activity and attention. The individual is "a site where messages arrive in many different lan-guages or codes, and where some of the messages are successfully translated into other codes, while others are not" (Reddy, 2001, p. 80). For a practice theoretical analysis of the pupil as a subject, see Reh, S. (2013). Die Produktion von (Un-)Selbständigkeit in individualisierenden Lernformen. Zur Analyse von schulischen Subjek-tivierungspraktiken. In A. Gelhard, T. Alkemeyer, \& N. Ricken (Eds.), Techniken der Subjektivierung (pp. 189-200). Munich, Germany: Fink.

11. See also Biernacki (2005).

12. Füssel criticizes the term of "source" (German: quelle) because this metaphor always concerns the aura of origin, which must be called into question in the 
same way as the idea of an archive as a location where objective data are collected that is, actually containing history (Friedrich, 2013, pp. 266-270). Füssel postulates this against the background of the actual work of a historian described by Lorraine Daston (2011), perceivable in terms of laboratory studies, particular practices and allowing for identification of participants in such practices - for example, as a historian (Füssel, 2014b, p. 4).

13. For a German example, see Bödeker, H. E., \& Hinrichs, E. (Eds.). (1999). Alphabetisierung und Literalisierung in Deutschland in der frühen Neuzeit. Tübingen, Germany: Max Niemeyer.

14. This quotation appeared in a manifesto of the Société des Observateurs de l'homme,' written by L.-F. Jauffret, published in 1799, reprinted in Moravia (1973, pp. 209-219).

15. The title could be translated in English as Magazine on the Study of the Soul Based on Experience; Moritz coined the term Erfahrungsseelenkunde (Rölz, 2012, p. 17). It was reprinted in the Federal Republic of Germany in 1986.

16. For instance, Baur (1859) - in an encyclopedia of education and instruction (Enzyklopädie des gesammten Erziehungs- und Unterrichtswesens) edited by Karl Schmid listed the keyword Beobachtung (observation) (p. 560).

17. In the following, I refer to the habilitation project by Kathrin Berdelmann titled "Pädagogische Beobachtung - Zur historischen Etablierung einer Reflexionskategorie pädagogischer Praxis," which is carried out at BBF respectively Humboldt University Berlin. See also Reh, S., Berdelmann, K., \& Scholz, J. (2014, forthcoming). Der Ehrtrieb und unterrichtliche Honorierungspraktiken im Schulwesen um 1800 - Die Entstehung des Leistungs-Dispositivs. In A. Schäfer \& C. Thompson (Ed.), Leistung. Paderborn, Germany: Schöning.

18. The first book of merits in Dessau was begun by Campe himself in 1777. For his reasoning and argumentation see Campe (1777a, 1777b). Each student was assigned several pages recorded in tabular style. The date is noted in the first column, and the second documented collected tokens for diligence (a stroke marked achievement of 50 tokens and the first number behind the stroke is the add-carry). The third column documented estimations and observations of student behavior - generally relating to immediately observable diligence conduct demon-strated in a previous lesson. Progress was also noted there. The last column documented tokens discounted for negative conduct. Fifty tokens equaled one score on the table of merits. Scores were assigned for diligence and virtue. However, after two months (March to May 1777), virtue was no longer recorded. Campe believed that there was no means of assessing virtue. Hence, only diligence was recorded - as the first category with immedi-ate relation to what teachers experience in lessons or as a result of assiduous conduct at home as observed in lessons. The second book of merits from the Dessau Philanthropinum began recording around 1783. The way of writing about students had changed. Records were now more detailed and because they were more explicit, they were also more individual. For this correlation, see Reh, Berdelmann, \& Scholz (2014); further sources and ref-erences can be found there.

19. This is also repeatedly documented in writings from Prussian school 
administration from the 1820 s, 1830s, and 1840s. For instance, there is a ministerial address to the province teachers in Coblenz from May 12, 1840, indicating that it is the teacher's task to observe students according to their individuality (von Rönne, 1855, p. 193).

20. This can also be found in the address from the Minister to teaching staff dated May 12, 1840 (von Rönne, 1855, pp. 192-194).

21. "German" refers to instruction in German language and literature, which developed in schools in the German-speaking states over the course of the 19th century.

22. See, for example, the attempt at a comprehensive history of German lessons by Frank, H. J. (1973). Dichtung, Sprache, Menschenbildung. Geschichte des Deutschunterrichts von den Anfängen bis 1945. Munich, Germany: Carl Hanser. For a more recent example, see Kämper-van den Boogart, M. (2010). Geschichte des Leseund Literaturunterrichts. In M. Kämper-van den Boogart \& K. H. Spinner (Ed.), Lese- und Literaturunterricht (Teil 1: Geschichte und Entwicklung: Konzeptionelle und empirische Grundlagen, pp. 3-83). Baltmannsweiler, Ger-many: Schneider Verlag Hohengehren.

23. For example, Frank (1973), Jäger (1981), Abels (1986), and most recently Kämper-van den Boogart (2010).

24. First published in 1843; here, the 1851 edition is quoted.

25 . The first edition was published in 1852; the 6th edition (1897) is quoted here.

26. In an examination of the work of Hiecke, Abels (1986) writes that "in the 140 years which have passed since the book's publishing, much of that which Hiecke describes in great detail has become self-evident" (p. 113). Similar, too, is Jäger's (1981, pp. 40-41) estimation of the prevailing methods of Hieckes. General estimations of the literature following him in historical research on German lessons state that Hiecke on the one side and Wackernagel - or rather, Raumer - on the other side represent the opposing figures (Laas, 1872, p. 113). The task of the reading of German literature is far more to convey than to explain: the "aesthetic diessection and commenting method is of no use." One doesn't need to explain, that should be left to the common sense of the student (Laas, 1872, p. 121). Similarly, in Abels (1986): "An important means of differentiation between this restaurative pedagogy and Hiecke are the methods, which are suggested to convey literature. Günther, Raumer and others saw the task of the school to 'deliver poetry as poetry"' (p. 155).

27. Lessons in the mother tongue directed towards production, which are based on the reading of corresponding texts, was intended by Hiecke (1842, p. 16); he writes: "In this way the richest possibilities open themselves up to equally interesting as educational tasks for free oral presentations as well as written work" (p. 120).

28. Süvern had called for class reading in 1816; in 1820, Bernhardi introduced it in Berlin, and in the 1830s it was counseled among headmasters and a corresponding reader was called for. Indeed, there were forms of class reading in some schools at the time that Hiecke wrote his book - admittedly, more for the purpose of forming style than for the purpose of general education - at least according to the assessment of Frank (1973). 
29. At the same time, this practice could serve the production of a particular subject - a subject of hermeneutic practices in and through German lessons. For research "on the production of a hermeneutic way of life in the 19th century," see Gumbrecht, H. U. (1996). Das Nicht-Hermeneutische: Skizze einer Genealogie. In J. Huber \& A. M. Müller (Ed.), Die Wiederkehr des Anderen (pp. 17-35). Basel, Switzerland, and Frankfurt, Germany: Stroemfeld/Roter Stern.

\section{References}

Abels, K. (1986). Zur Geschichte des Deutschunterrichts im Vormäræ: Robert Heinrich Hiecke (18051861) - Leben, Werk, Wirkung. Cologne, Germany, and Vienna, Austria: Böhlau.

Alkemeyer, T. (2013). Subjektivierung in sozialen Praktiken. Umrisse einer praxeologischen Analytik. In T. Alkemeyer, G. Budde, \& D. Freist, (Eds.), Selbst-Bildungen: Soziale und kulturelle Praktiken der Subjektivierung (pp. 33-67). Bielefeld, Germany: transcript Verlag. http://dx.doi.org/10.14361/transcript.9783839419922

Alkemeyer, T., Budde, G., \& D. Freist (Eds.). (2013). Selbst-Bildungen: Soziale und kulturelle Praktiken der Subjektivierung. Bielefeld, Germany: transcript Verlag. http://dx.doi. org/10.14361/transcript.9783839419922

Austermann, S. (2010). Die 'Allgemeine Revision. 'Pädagogische Theorieentwicklung im 18. Jabrbundert. Bad Heilbrunn, Germany: Klinkhardt.

Bachmann-Medick, D. (2009). Cultural turns: Neuorientierungen in den Kulturwissenschaften (3rd ed.). Reinbek, Germany: Rowohlt.

Bachmann-Medick, D. (2013). Turn(s). In U. Frietsch \& J. Rogge (Eds.), Über die Praxis kulturwissenschaftlichen Arbeitens: Ein Handwörterbuch (pp. 399-404). Bielefeld, Germany: transcript Verlag.

Baur, G. (1859). Beobachtung. In K.-A. Schmid (Ed.), Encyklopädie des gesammten Eržiehungsund Unterrichtswesens (Vol. 1, pp. 560-565). Gotha, Germany: Verlag von Rudolf Besser.

Biernacki, R. (1999). Method and metaphor after the new cultural history. In V. E. Bonnell \& L. Hunt (Eds.), Beyond the cultural turn: New directions in the study of society and culture (pp. 62-92). Berkeley and Los Angeles, CA, and London, England: University of California Press.

Biernacki, R. (2005). Language and the shift from signs to practices in cultural inquiry. In G. M. Spiegel (Ed.), Practicing history: New directions in historical writing after the linguistic turn (pp. 228-244). New York, NY, and London, England: Routledge.

Bourdieu, P. (1979). Entwurf einer Theorie der Praxis auf der ethnologischen Grundlage der kabylischen Gesellschaft. Frankfurt, Germany: Suhrkamp.

Brachmann, J. (2008). Der pädagogische Diskurs der Sattelzeit: Eine Kommunikationsgeschichte. Bad Heilbrunn, Germany: Klinkhardt.

Campe, J. H. (1777a). Von der eigentlichen Absicht eines Philanthropins. In J. B. Basedow \& J. H. Campe (Eds.), Pädagogische Unterhandlungen (Vol. 1, part 1, pp. 14-59). Dessau, Germany: Steinacker.

Campe, J. H. (1777b). Ob es rathsam sey, die Ehrbegierde zu einer moralischen Triebfeder 
bey der Erziehung zu machen. In J. B. Basedow \& J. H. Campe (Eds.), Pädagogische Unterbandlungen (Vol. 1, part 3, pp. 271-278). Dessau, Germany: Steinacker.

Campe, J. H. (1998). Über das Zweckmäßige und Unzweckmäßige in den Belohnungen und Strafen. B. Ofenbach (Ed.). Heinsberg, Germany: Dieck.

Casale, R., Oelkers, J., \& Tröhler, D. (Eds.). (2006). Methoden und Kontexte: Historiographische Probleme der Bildungsforschung. Göttingen, Germany: Wallstein.

Daniel, U. (2001). Kompendium Kulturgeschichte: Theorien - Praxis - Schlüsselwörter. Frankfurt, Germany: Suhrkamp.

Daston, L. (2011): The empire of observation, 1600-1800. In L. Daston \& E. Lumbeck (Eds.), Histories of scientific observation (pp. 81-113). Chicago, IL, and London, England: The University of Chicago Press.

Depaepe, M. (2000). Order in progress: Everyday education. Practice in primary schools - Belgium, 1880-1970. Leuven, Belgium: University Press.

Diele, H., \& Schmid, P. (2010). Zu den Anfängen empirischer Kinderforschung in Deutschland. In C. Ritzi \& U. Wiegmann (Eds.), Beobachten - Messen - Experimentieren (pp. 51-76). Bad Heilbrunn, Germany: Klinkhardt.

Diesterweg, A. (1835). Das pädagogische Deutschland der Gegenwart oder: Sammlung von Selbstbiographien jetżt lebender, deutscher Erzieher und Lehrer; für Erziehende. Berlin, Germany: Plahn.

Friedrich, M. (2013). Die Geburt des Archivs: Eine Wissensgescbicbte. Munich, Germany: Oldenbourg. http://dx.doi.org/10.1524/9783486780949

Freist, D. (2013a). Dress to impress: Mode als materielle Praktik sozialer Distinktion in der ländlichen Oberschicht Nordwestdeutschlands. In D. Freist \& F. Schmekel (Eds.), Hinter dem Horizont: Projektion und Distinktion ländlicher Oberschichten im europäischen Vergleich 17. Bis 19. Jahrbundert (Vol. 2, pp. 91-103). Münster, Germany: Aschendorff.

Freist, D. (2013b). 'Ich will Dir selbst ein Bild von mir entwerfen.' Praktiken der SelbstBildung im Spannungsfeld ständischer Normen und gesellschaftlicher Dynamik. In T. Alkemeyer, G. Budde, \& D. Freist (Eds.), Selbst-Bildungen: Soziale und kulturelle Praktiken der Subjektivierung (pp. 151-174). Bielefeld, Germany: transcript Verlag.

Füssel, M. (2006). Gelehrtenkultur als symbolische Praxis: Rang, Ritual und Konflikt an der Universität der Frühen Neuzeit. Darmstadt, Germany: WBG.

Füssel, M. (2014a, forthcoming). Lehre ohne Forschung? Die Praxis des Wissens an der vormodernen Universität. In: M. Kintzinger (Ed.), Universitäre Wissenskulturen. Basel, Switzerland.

Füssel, M. (2014b, forthcoming). Praktiken historisiere: Geschichtswissenschaft und Praxistheorie im Dialog. In F. Schäfer, A. Daniel, \& F. Hillebrandt (Eds.), Methoden einer Soziologie der Praxis. Bielefeld, Germany: transcript Verlag.

Füssel, M., \& Sikora, M. (Eds.) (2014). Kulturgeschicbte der Schlacht. Paderborn, Germany: Schöningh.

Geertz, C. (1983). Dichte Beschreibung. Frankfurt, Germany: Suhrkamp.

Giddens, A. (1995). Die Konstitution der Gesellschaft: Grundzüge einer Theorie der Strukturierung. Frankfurt, Germany, and New York, NY: Campus.

Groppe, C. (2012). History of education in Germany: Historic development - Results - raison d'etre. In J. E. Larsen (Ed.), Knowledge, politics and the history of education (pp. 
179-193). Berlin, Germany: LIT.

Hicks, D. (2010). The material-cultural turn: Event and effect. In D. Hicks \& M. C.

Beaudry (Eds.), The Oxford handbook of material culture studies (pp. 25-98). Oxford, England: Oxford University Press.

Hiecke, R. H. (1842). Der deutsche Unterricht auf deutschen Gymnasien: Ein pädagogischer Versuch. Leipzig, Germany: Eduard Eisenach.

Hütig, A. (2010). Dimensionen des Kulturbegriffs. In J. Kusber, M. Dreyer, J. Rogge, \& A. Hüᄀtig (Eds.), Historische Kulturwissenschaften: Positionen, Praktiken und Perspektiven (pp. 105-124). Bielefeld, Germany: transcript Verlag.

Jäger, G. (1981). Schule und literarische Kultur: Sozialgeschichte des deutschen Unterrichts an böheren Schulen von der Spätauflelärung bis zum Vormärz, (Band 1: Darstellung). Stuttgart, Germany: J. B. Metzlersche Verlagsbuchhandlung.

Kersting, C. (1992). Die Genese der Pädagogik im 18. Jabrbundert. Campes 'Allgemeine Revision' im Kontext der neuzeitlichen Wissenschaft. Weinheim, Germany: Deutscher Studien Verlag.

Kittler, F. A. (2003). Aufschreibesysteme 1800/1900 (4th ed.). Munich, Germany: Fink.

König, G. M. (Ed.). (2005). Alltagsdinge: Erkundungen der materiellen Kultur. Tübingen, Germany: TVV.

Kusber, J., Dreyer, M., Rogge, J., \& Hütig, A. (Eds.). (2010). Historische Kul $\neg$ tur $\neg w i-$ ssenschaften: Positionen, Praktiken und Perspektiven. Bielefeld, Germany: transcript Verlag. http://dx.doi.org/10.14361/transcript.9783839414415

Laas, E. (1872). Der Deutsche Unterricht auf böheren Lebranstalten: Ein kritisch-organisatorischer Versuch. Berlin, Germany: Weidmann.

Lorenz. (1902). Die Meritenbücher und Meritentafeln des Pbilanthropinums in Dessau. In Mitteilungen der Gesellschaft für Deutsche Erziehungs- und Schulgeschichte (Vol. 12, part 2, pp. 93-121). Berlin, Germany.

Matthias, A. (1907). Geschichte des deutschen Unterrichts. Munich, Germany: Beck. (Also published as Matthias, A. Handbuch des deutschen Unterrichts an böberen Schulen, Vol. 1, part 1).

Maurer, M. (2005). Alte Kulturgeschichte - Neue Kulturgeschichte. Historische Zeitschrift, 280, 281-304.

Miller, D. (Ed.). (2005). Materiality. Durham, NC: Duke University Press. http://dx.doi. org/10.1215/9780822386711

Moravia, S. (1973). Beobachtende Vernunft: Philosophie und Anthropologie in der Aufklärung. Munich, Germany: Carl Hanser.

Moritz, K.-Ph.(Ed.). (1986). Gnothi Seauton oder Magazin zur Erfahrungsseelenkunde als ein Lesebuch für Gelehrte und Ungelehrte. Erster Band, Erstes bis Drittes Stück 1783. Nördlingen, Germany: Franz Greno.

Paefgen, E. K. (2006). Einführung in die Literaturdidaktik (2nd ed.). Stuttgart, Germany: J. B. Metzler.

Polanyi, M. (1985). Das implizite Wissen. Frankfurt, Germany: Suhrkamp.

Raumer, R. von. (1897). Der Unterricht im Deutschen. In K. von Raumer, Geschichte der Pädagogik, vom Wiederaufblïhen klassischen Studien bis auf unsere Zeit (6th ed., part 3:2). Gütersloh, Germany: Bertelsmann.

Reckwitz, A. (2000). Die Transformation der Kulturtheorien: Zur Entwicklung eines Theorieprogramms. Weilerswist, Germany: Velbrück. 
Reckwitz, A. (2003). Grundelemente einer Theorie sozialer Praktiken: Eine sozialtheoretische Perspektive. Zeitschrift für Soziologie, 32(4), 282-301.

Reddy, W. M. (2001). The navigation of feeling: A framework, for the bistory of emotions. New York, NY: Cambridge University Press. http://dx.doi.org/10.1017/CBO9780511512001

Reh, S. (2014). Prekarisierung der Profession: Historische Autorisierungsmuster zwischen Profession und Expertise. In F. Kessl, A. Polutta, I. van Ackeren, R. Dobischat, \& W. Thole (Eds.), Prekarisierung der Pädagogik - Pädagogische Prekarisierung? Erziehungswissenschaftliche Vergewisserungen (pp. 27-42). Weinheim, Germany, and Basel, Switzerland: Beltz.

Reinhardt, S. (2007). Praxeologische Geschichtswissenschaft: Eine Diskussionsanregung. Sozial. Geschichte. Zeitschrift für historische Analyse des 20. und 21. Jabrbunderts, 22(3), 43-65.

Ricken, N. (2013). Anerkennung als Adressierung: Über die Bedeutung von Anerkennung für Subjektivationsprozesse. In T. Alkemeyer, G. Budde, \& D. Freist (Eds.), SelbstBildungen: Soziale und kulturelle Praktiken der Subjektivierung (pp. 69-99). Bielefeld, Germany: transcript Verlag.

Rölz, E. (2012). A new frontier in the eighteenth century: Karl Philipp Moritz and the exploration of the human mind. International Journal of Business, Humanities and Tecbnology, 2(4), 17-22.

Rönne, L. von. (1855). Das Unterrichts-Wesen des Preußischen Staates, Zweiter Band: Höhere Schulen, Universitäten, Sonstige Kultur-Anstalten. Berlin, Germany: Veit \& Comp.

Ruppert, W. (1993). Fahrrad, Auto, Küblschrank: Zur Kulturgeschicbte der Alltagsdinge. Frankfurt, Germany: Suhrkamp.

Sarasin, P. (2013). Routine. In U. Frietsch \& J. Rogge (Eds.), Über die Praxis kulturwissenschaftlichen Arbeitens: Ein Handwörterbuch (pp. 352-357). Bielefeld, Germany: transcript Verlag.

Schatzki, T. R. (1996). Social practices: A Wittgensteinian approach to buman activity and the social. Cambridge, England: Cambridge University Press. http://dx.doi.org/10.1017/ CBO9780511527470

Schatzki, T. R. (2002). The site of the social: A philosophical account of the constitution of social life and change. University Park, PA: The Pennsylvania State University Press.

Schatzki, T. R. (2010). The timespace of human activity: On performance, society, and history as indeterminate teleological events. Lanham, MD: Lexington Books.

Schatzki, T., Knorr Cetina, K., \& von Savigny, E. (Eds.). (2001). The practice turn in contemporary theory. London, England, and New York, NY: Routledge.

Schings, H.-J. (1977). Melancholie und Aufklärung: Melancholiker und ibre Kritiker in Erfahrungsseelenkunde und Literatur des 18. Jahrbunderts. Stuttgart, Germany: J. B. Metzler.

Schläppi, D. (2013). Schul-, Praxis- und habituelles Herrschaftswissen. Bildung ländlicher Eliten mit Blick auf die korporative Selbstverwaltung in der frühmodernen Schweiz (18. und 19. Jahrhundert). In D. Freist \& F. Schmekel (Eds.), Hinter dem Horizont: Projektion und Distinktion ländlicher Oberschichten im europäischen Vergleich 17. Bis 19. Jabrbundert (Vol. 2, pp. 235-248). Münster, Germany: Aschendorff.

Steckel, S. (2011). Kulturen des Lehrens im Früh-und Hochmittelalter: Autorität, Wissenskonzepte und Netzwerke von Gelehrten. Cologne and Weimar, Germany, and Vienna, Austria: Böhlau Verlag.

Tenorth, H.-E. (2004). Erziehungswissenschaft. In D. Benner \& J. Oelkers (Eds.), Historisches 
Wörterbuch der Pädagogik (pp. 341-381). Weinheim, Germany, and Basel, Switzerland: Beltz.

Tenorth, H.-E. (2009). Historische Bildungsforschung. In R. Tippelt \& B. Schmidt (Eds.), Handbuch Bildungsforschung (2nd ed., pp. 135-153). Wiesbaden, Germany: VS Verlag für Sozialwissenschaften.

Tietmeyer, E., Hirschberger, C., Noack, K., \& Redlin, J. (Eds.). (2010). Die Sprache der Dinge: Kulturwissenschaftliche Perspektiven auf die materielle Kultur. Münster, Germany: Waxmann.

Tschopp, S. S. (2009). Die neue Kulturgeschichte - eine (Zwischen-) Bilanz. Historische Zeitschrift, 289, 573-605. http://www.degruyter.com/view/j/hzhz.2009.289.issue-3/ hzhz.2009.0051/hzhz.2009.0051.xml

Vierhaus, R. (Ed.). (1995). Die Rekonstruktion historischer Lebenswelten: Probleme moderner Kulᄀturgeschichtsschreibung. In Wege zu einer nenen Kulturgeschichte (Göttinger Gespräche zur Geschichtswissenschaft 1, pp. 7-28). Göttingen, Germany: Wallstein.

Wackernagel, P. (1851). Der Unterricht in er Muttersprache (new revised ed.). Stuttgart, Germany: S. G. Liesching.

Wezel, J. K. (1778). Noch eine Apologie des Ehrtriebs. In J. B. Basedow \& J. H. Campe (Eds.), Pädagogische Unterhandlungen (Vol., 2, part 1, pp. 68-101). Dessau, Germany: Steinacker. 
